\title{
Geografia urbana setecentista e turismo: as praças de Mariana - Brasil sob a perspectiva experiencial
}

\section{Lauro Almeida de Moraes* Saulo Rondinelli Xavier da Silva** José Manoel Gândara****}

Universidade Federal do Paraná (Brasil)

\begin{abstract}
Resumo: Este artigo tem como objetivo analisar praças da cidade histórica de Mariana (Minas Gerais - Brasil) enquanto espaços de experiências turísticas. A pesquisa baseou-se, conceitualmente, em discussões sobre espaço público, tipos e funções de praças, experiência turística e traçado urbano de Mariana. Como premissa metodológica, trata-se de um estudo exploratório e descritivo, de cunho qualitativo, que utiliza revisão crítica de literatura e netnografia, a partir de imagens fotográficas e avaliações das praças da Sé, Gomes Freire e Minas Gerais compartilhadas no website TripAdvisor ${ }^{1}$. Dessa forma, a pesquisa avalia percepções e representações de turistas acerca dos espaços sob investigação, cotejando-as com o levantamento histórico-geográfico sobre o urbanismo setecentista de Mariana. Os resultados indicam que as praças estudadas são representativas para a história do Brasil, particularmente de Minas Gerais, e para a realização de práticas turísticas memoráveis. A conservação e gestão eficiente desses espaços são, portanto, fundamentais para a memória autóctone e a sustentabilidade da atividade turística.
\end{abstract}

Palavras-chave: Espaço público; Experiência turística; Urbanismo setecentista; Reputação online; Mariana.

$18^{\text {th }}$ century urban geography and tourism: the squares of Mariana - Brazil from an experiential perspective

Abstract: This article aims at analyzing public space such as the squares of the historical city of Mariana (Minas Gerais - Brazil) as places for experiences in tourism. The research is conceptually based on discussions of public space, types and functions of squares, tourist experiences and the urban layout of Mariana. As a methodological premise, it is an exploratory, descriptive and qualitative study, which uses a critical review of the literature, images and evaluations shared on the TripAdvisor website about the following squares: Praça da Sé, Gomes Freire and Minas Gerais. Thus, the research evaluates tourist perceptions and representations of these spaces, comparing them with the historical-geographic survey of Mariana's $18^{\text {th }}$ century town development. The results indicate that the studied squares are representative of the history of Brazil, particularly of Minas Gerais, and apt for creating memorable touristic practices. Therefore, the conservation and efficient management of these spaces are fundamental for the autochthonous memory and the sustainability of tourism.

Keywords: Public space, Tourist experience, $18^{\text {th }}$ century urbanism; Online reputation; Mariana.

\section{Introdução}

Tombada como Monumento Nacional em 1945, Mariana ${ }^{2}$ foi a primeira cidade a ser projetada em Minas Gerais - Brasil. A descoberta de ouro às margens do rio batizado de Ribeirão Nossa Senhora do Carmo, em 1696, tornou a região estratégica para os interesses da Coroa Portuguesa, dando origem à primeira vila e capital da então Capitania de São Paulo e Minas de Ouro, até 1720. Em menos de meio século, já havia

\footnotetext{
* Doutorando em Geografia, Universidade Federal do Parana, Brasil; E-mail: lauromoraes@ufpr.br

** Doutorando em Geografia , Universidade Federal do Parana, Brasil; E-mail: geoilheus@hotmail.com

*** Doutor em Turismo e Desenvolvimento Sustentável (ULPGC, Las Palmas de Gran Canaria, Espanha), Professor na Universidade Federal do Parana, Brasil; E-mail: jmggandara@yahoo.com.br
} 
sido elevada à categoria de cidade e tornando-se também um centro religioso, sediando o primeiro bispado mineiro. Crescimento e pujança que logo exigiram um planejamento urbanístico. Este ficou caracterizado como único núcleo setecentista de Minas Gerais com traçado regular. Todavia, as intervenções urbanas registradas na historiografia - fundamentadas na cartografia militar - foram desempenhadas em meio a ajustes e controvérsias carentes de documentação mais precisa, como assinala Fonseca (2012, p. 92):

[...] o traçado do chamado "centro histórico" não deve ser associado exclusivamente ao "plano Alpoim" - sobre o qual, aliás, pairam várias dúvidas, já que a correspondência oficial demonstra que ele não participou de decisões essenciais, como a localização da "nova praça" da cidade (a atual praça que reúne a Casa de Câmara e as igrejas de São Francisco e Nossa Senhora do Carmo). Outros indivíduos, e diferentes instâncias do poder civil e religioso, participaram de maneira significativa na construção desse espaço urbano, além da própria população, que também interferiu no processo, ora se submetendo, ora reagindo às decisões das diversas autoridades.

Embora seja polêmico o debate, o traçado quase ortogonal, com ruas em linha reta e praças retangulares tornou-se uma característica física do Centro Histórico de Mariana associada ao projeto inicial, atribuído ao engenheiro militar português José Fernandes Pinto de Alpoim (Fonseca, 1995; Prefeitura de Mariana, 2017; Câmara Municipal de Mariana, 2017) (Figura 1).

\section{Figura 1: Planta da Cidade de Mariana (atribuída a José Fernandes Pinto Alpoim)}

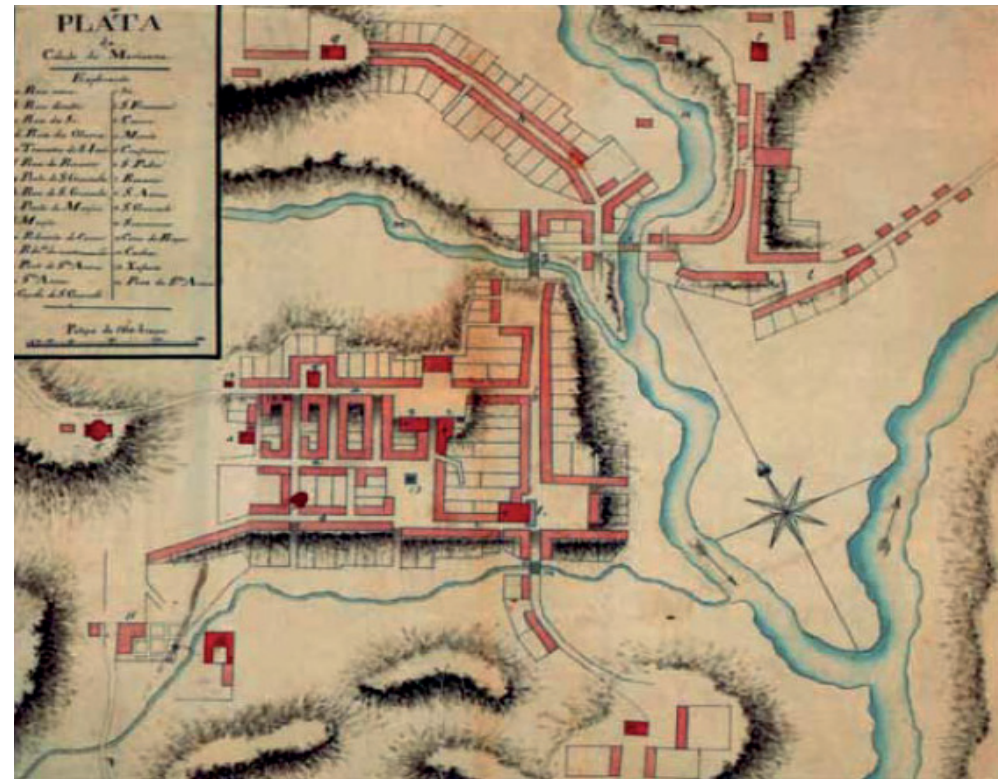

Fonte: Arquivo Histórico do Exército, Rio de Janeiro.

Tais atributos também estão registrados na obra do naturalista francês Auguste de Saint-Hilaire, que viajou pelo Brasil durante o século XIX, tendo descrito costumes e paisagens do país à época.

A cidade de Mariana é rasgada por ruas longitudinais, que cortam outras ruas oblíquas relativamente às primeiras, e, aproximadamente, paralelas entre si. As ruas longitudinais, que seguem à crista da colina, vão descendo de modo insensível; as transversais se estendem ao flanco da colina por uma rampa um tanto íngreme. Todas são regularmente pavimentadas e, em geral direitas e bastante largas, principalmente as duas ruas longitudinais chamadas Rua Direita e Rua das Cortes. A primeira leva à praça chamada da Cadeia (lugar da prisão), a outra termina na chamada das Cavalhadas (local dos Torneios) (Saint-Hilaire, 1975, p. 79). 
Localizadas no epicentro do núcleo histórico, região em que estão concentrados os principais conjuntos arquitetônicos e, por conseguinte, atrativos turísticos, essas duas praças seguem entre as principais de Mariana. E o destaque conferido a ambas por Saint-Hilaire (1975) confirma a importância político-administrativa da Praça da Cadeia (atual Praça Minas Gerais) e como espaço de vivência social da Praça das Cavalhadas (atual Praça Dr. Gomes Freire) já naquela época.

É no meio da praça da Cadeia que está a coluna encimada pela esfera dourada que indica ser a cidade sede de uma jurisdição. Essa praça é pequena e quadrada. Um dos seus lados é formada pela casa da câmara [...], dois dos outros lados são ocupados por outras tantas igrejas. A praça chamada das Cavalhadas é um quadrilátero alongado e coberto de grama; é lá que nos festejos públicos se fazem as corridas a cavalo e os torneios (Saint-Hilaire, 1975, p. 79).

Essa concepção urbana, com várias praças, diferencia Mariana das demais vilas de origem portuguesa. Como ressaltam Alves, Figueiredo e Paiva (2010), o mais comum era a existência de apenas uma praça, ao redor da qual ficavam as principais edificações públicas e o tempo católico romano. Dessa forma, às duas praças supracitadas, soma-se uma terceira que figura como espaço referencial de Mariana: a Praça da Sé.

Esses lugares referenciais constituem-se também, pelo seu significado patrimonial e urbanístico, espaços atrativos para o turismo. Visitantes, assim como moradores, relacionam-se dialeticamente com tais espaços, e as respostas manifestadas diante das sensações são espontaneamente expressadas. Nesse contexto, considerando as praças como espaços públicos de experiências turísticas, este artigo desenvolveu-se a partir da seguinte questão: como se dá o diálogo entre o passado e o presente de praças da cidade de Mariana - MG, a partir da percepção de visitantes? Buscando atender a este problema, objetivou-se analisar praças de Mariana enquanto espaços de experiências turísticas, considerando fotografias e depoimentos veiculados no website TripAdvisor, com base na percepção e representação dos visitantes.

\section{As Praças de Mariana: fragmentos de um traçado urbano setecentista}

O ponto de partida deste artigo foram discussões sobre as praças da Sé, Gomes Freire e Minas Gerais, considerando seus significados urbanísticos. Dessa forma, realizou-se um levantamento histórico-geográfico, a fim de balizar a constituição, evolução e relevância socioespacial dessas praças. Os subsídios confirmam a importância desses espaços para a sociabilidade local, bem como para a memória nacional, especialmente de Minas Gerais.

\subsection{Praça da Sé}

Os registros do inglês John Luccock, que permaneceu no Brasil entre 1808-1818, trazem alusões morfológicas, climáticas e ao aspecto urbano de Mariana, pinçando uma menção ao que hoje é a Praça da Sé.

Estando a cidade de Mariana encostada a quinhentos pés abaixo de Vila Rica, e, além disso, cercada de elevados montes, é ela confinada e quente. É aproximadamente quadrada, consistindo principalmente de duas ruas bem calçadas e traçadas com regularidade, que conduzem a uma espécie de largo ou praça (Luccock, 1942, p. 340).

Conforme relatam Gonçalves e Sousa (2012), esse espaço nasce no esteio de uma reorientação do núcleo urbano, no início do século XVIII, quando a elite começa a se transferir da região onde ficava a Igreja do Rosário Velho - atual Capela de Santo Antônio - para as adjacências da nova Matriz. O estudo de Bastos (2015), que acessou atas da Câmara Municipal de Vila Rica daquele período, confirma a decisão de arruadores e camaristas em tornar as imediações da praça da Igreja Matriz de Nossa Senhora do Pilar mais "vistosa", determinando o realinhamento da rua nos seus arredores. O autor respeita a grafia original usada nos documentos públicos da época.

Em 1714, após o incêndio que havia danificado algumas casas na praça em frente à igreja, os vereadores resolveram "fazer vistoria nas cazas ensemdiadas [incendiadas] no bairro de ouro pretto para que se aRuacem de sorte que ficasse a praça suficiente por ser defronte da igreja para ficar mais vistoza aquella Rua. Acordaram, então, [...] "medindo e aRuando as de sorte que Recuacem p. ${ }^{a}$ os fundos e ficasse huma praça p. ${ }^{a}$ milhor aRuament. ${ }^{o}$ desta nova V. ${ }^{a}$ [Vila] e por ficar defronte da matris daquele BaiRo (Bastos, 2015, destaques e grifo do autor, p. 75). 
De frente para a Matriz e rodeada por casario do período colonial - hoje, fundamentalmente ocupados por estabelecimentos comerciais - a Praça da Sé - como é mais conhecida a Praça Cláudio Manoel da Costa - chegou a abrigar a Casa de Câmara, Audiência e Cadeia, construída ali entre 1731 e 1741 (Vasconcelos, 1999, p. 410). Ocupando uma área mais baixa da cidade, a região da praça ficava, porém, mais suscetível às constantes cheias do Ribeirão do Carmo. Mesmo com a implementação de melhorias urbanas em 1745, o protagonismo desse espaço ficou quase que exclusivamente tomado pela catedral. Após a criação do bispado de Mariana, o prédio que simbolizava o poder distanciou-se dali, ganhando uma construção com melhor estrutura no antigo Largo dos Quarteis, atual Praça Minas Gerais (Antunes \& Silveira, 2015, p. 22-24).

Figura 2: Praça da Sé na década de 1920

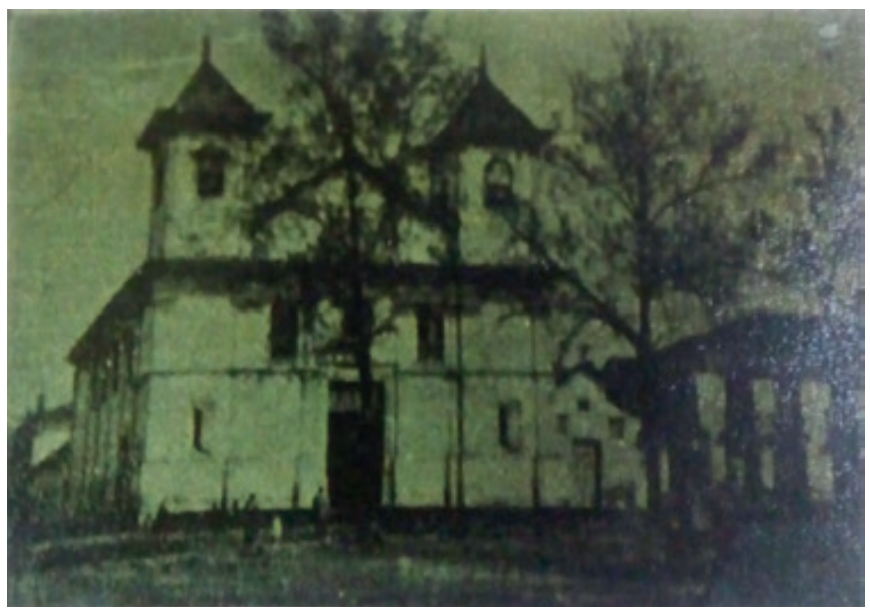

Fonte: Fonseca (1995)

Figura 3: Praça da Sé, com igreja em reforma à época.

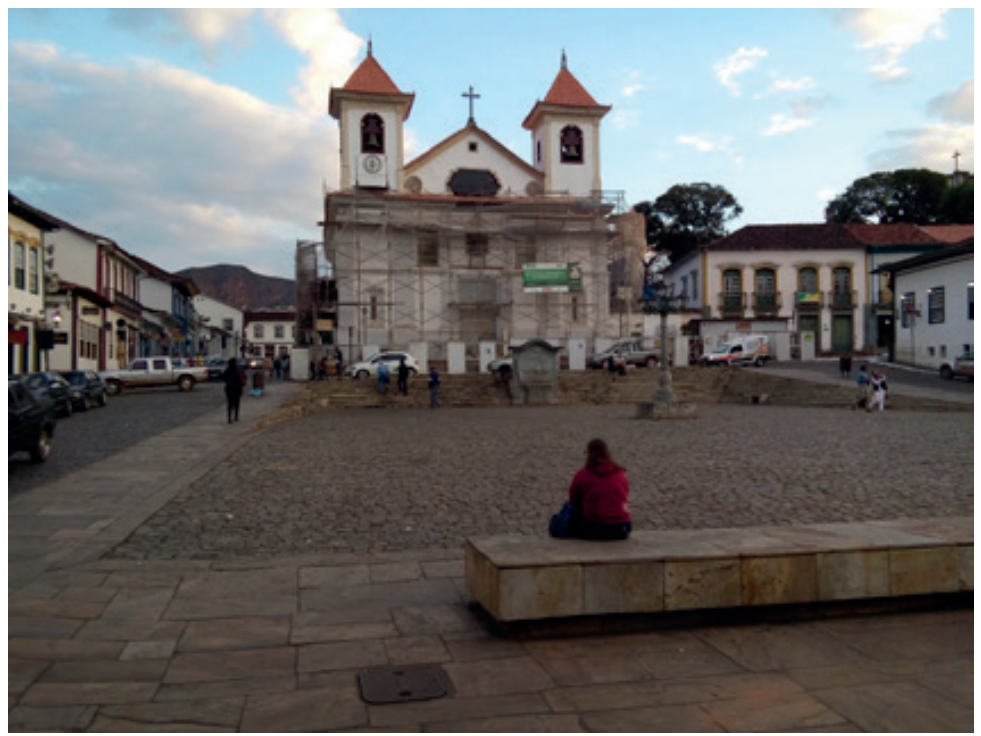

Fonte: Pesquisa de campo (2017) 
Situada ao fim da Rua Direita, a Praça da Sé pode ser definida, atualmente, mais como um espaço de passagem do que permanência. Favorece esta atribuição o fato de estar entre os principais corredores comerciais de Mariana, com fluxo intenso de veículos e pedestres nas três ruas que a circundam. Todavia, a limitação do mobiliário urbano - composto apenas por luminárias, um extenso assento sem cobertura vegetal ou construída e um chafariz inativo, do século XIX (Tedeschi, 2015, p. 121) - não são convidativos ao uso mais prolongado. Conforme se percebe na Figura 2, havia arborização até a década de 1920. Porém, sobretudo a partir do tombamento como Monumento Nacional, em 1945, revigora-se o conceito de eliminar referências urbanísticas e arquitetônicas ecléticas, ou seja, que não fossem barrocas (Fonseca, 1995). Dessa forma, a Praça da Sé passa a ter a feição atual (Figura 3). E a apropriação pelos moradores tem mais um sentido patrimonial, em virtude do significado religioso e histórico do local, do que propriamente em função do aspecto físico.

\subsection{Praça Minas Gerais}

O processo inverso - de valorização - ocorreu com a região dos antigos quartéis, que também passou a abrigar duas importantes ordens religiosas (Antunes \& Silveira, 2015, p. 24; Ferreira \& Ferreira, 2009). Dessa forma, além de espaço referencial de Mariana, a Praça Minas Gerais é uma imagem icônica. Isso fica evidenciado nas páginas dos jornais, sobretudo em datas cívicas, como a fundação de Mariana. No aniversário, essa iconografia ocupa a maior parte das homenagens prestadas ao município nos jornais (Figura 4) 3 $^{3}$ E foi especialmente recorrente nos 300 anos de Mariana, em 1996. Com efeito, do ponto das representações sociais, esse é o espaço que sintetiza, identifica e simboliza Mariana.

\section{Figura 4: Praça Minas Gerais em homenagens a Mariana no jornal "O Liberal", na década de 1990.}

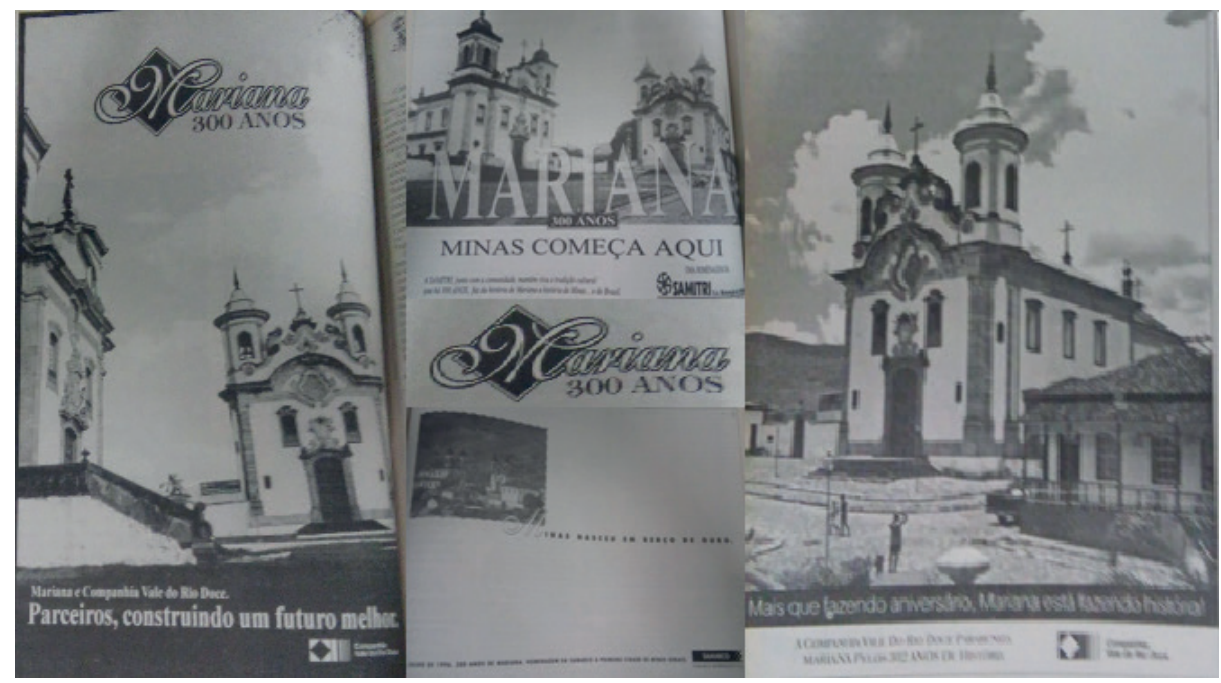

Fonte: Arquivo da Biblioteca Municipal Benjamim Lemos, com intervenção dos autores.

Como se observa nas imagens reproduzidas, a praça abriga um emblemático conjunto arquitetônico. Compõem a paisagem em formato de "U" edificações religiosas barrocas, um monumento e um destacado prédio em estilo colonial português, erguido entre 1782 e 1798. Frente a frente, estão a Igreja São Francisco e a Casa de Câmara e Cadeia (atual Câmara Municipal). Perpendicularmente, no cruzamento entre a Rua Dom Silvério e a Travessa São Francisco, fica a Igreja Nossa Senhora do Carmo. No centro da praça, diante da Câmara e da Cadeia, situa-se um conhecido símbolo da justiça e da relativa autonomia local durante o período colonial - o pelourinho (Antunes \& Silveira, 2015, p. 26). 
Em função do clima quente e temperado de Mariana, com temperatura média de $21.5^{\circ} \mathrm{C}$ e pluviosidade significativa ao longo do ano (média anual de $1307 \mathrm{~mm}$ ) (Climate-data.org, 2017) ${ }^{4}$, a inexistência de vegetação arbórea, de áreas cobertas ou de manchas de sombra reduz a sensação de conforto ambiental, dificultando a permanência por longos períodos. Acrescente-se a isso o calçamento de pedra e a falta de mobiliário urbano. Dessa forma, as escadarias das igrejas são frequentemente tomadas como lugar de assento, a que recorrem moradores e turistas que passam, encontram-se ou decidem ficar por ali algum tempo (Figuras 5 e 6).

Figura 5: Praça Minas Gerais

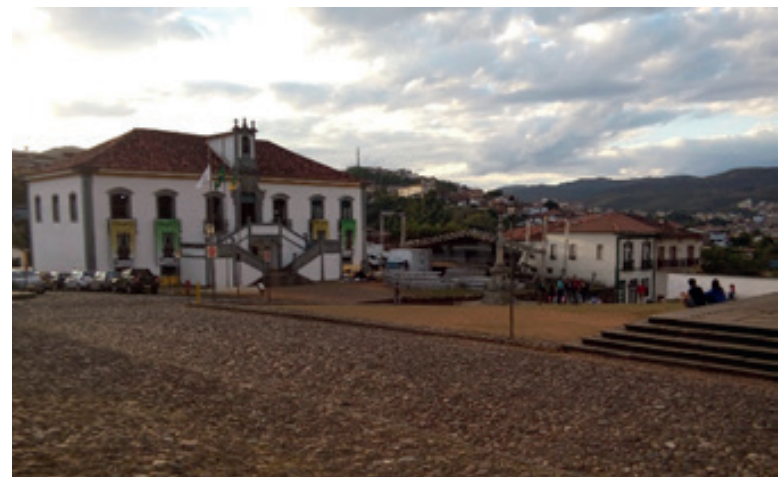

Fonte: Pesquisa de campo (2017).

Figura 6: Praça Minas Gerais

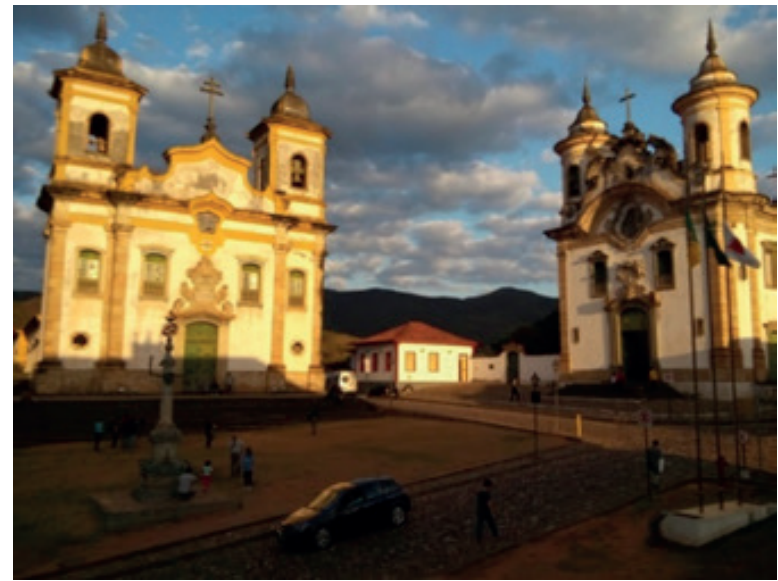

Fonte: Pesquisa de campo (2017).

Por outro lado, a ausência desses componentes da paisagem urbana, comuns às praças, confere amplitude ao espaço. Assim, tanto pela sua disposição espacial, quanto pela sua relevância histórica e patrimonial, a Praça Minas Gerais recebe grande parte dos eventos sociais, cívicos e políticos realizados em Mariana. Além de festivais e apresentações artísticas, é onde ocorre uma das solenidades mais significativas do estado. No Dia de Minas - instituído pela Lei 7561/1979 e referendado no artigo 256 da Constituição Estadual (Minas Gerais, 1989) - a capital mineira é simbolicamente transferida para Mariana em 16 de julho (Marton \& Pereira, 2007). Em homenagem à Cidade-Mãe de Minas, um ato cívico perfila as bandeiras de todos estados brasileiros (Figura 7). 
Figura 7: Dia de Minas na Praça Minas Gerais.

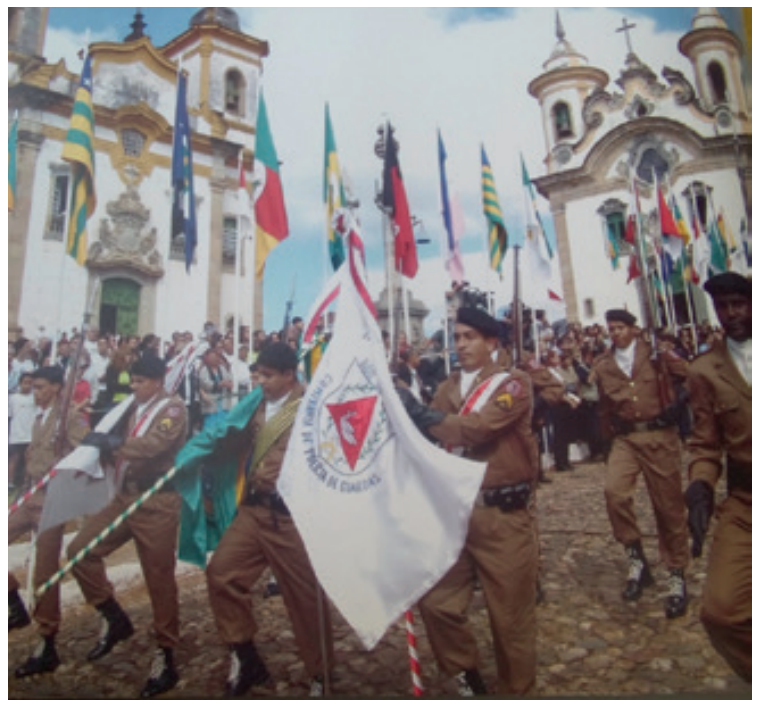

Fonte: Élcio Rocha - Catálogo de Mariana (2007).

Se as praças Minas Gerais e da Sé são eivadas de um sentido mais cívico e religioso, respectivamente, a Praça Dr. Gomes Freire carrega maior significância do ponto de vista da sociabilidade, como espaço de convivência, espaço vivido. Devido à falta de rigor na gestão no período em que foram abertas as primeiras ruas e praças da vila, é imprecisa a cronologia de sua evolução espacial. Todavia, registros dão conta que próximo de onde atualmente está a Gomes Freire, iniciou-se uma espontânea tradição de uso no início do século XVIII. "Era ali, no limite do Rossio ${ }^{5}$, que paravam os cavalos e as pessoas se prepararam para entrar ou sair da vila, desenvolvendo nesse espaço uma tradição de apropriação informal, um espaço popular" (Alves, Figueiredo \& Paiva, 2010, p. 13).

\subsection{Praça Gomes Freire}

A gênese da praça inicia-se como Largo do Rossio e, posteriormente, Largo das Cavalhadas ${ }^{6}$, sendo projetada para receber eventos populares e exercícios militares (Alves, Paiva \& Garcia, 2016, p. 351). Em 1717, o então governador da Capitania de São Paulo e Minas de Ouro D. Pedro de Almeida e Portugal, condecorado Conde de Assumar, passou a residir nessa região. O palácio - ainda preservado - seria também residência do primeiro bispo de Mariana, D. Frei Manuel da Cruz, que se instalou ali em 1748. E só não teria ocorrido a instalação da Casa de Câmara e Cadeia nas proximidades porque o entorno já estaria ocupado. A despeito destes indicativos de valorização do local, as vagas referências quanto ao ajardinamento são posteriores à Proclamação da República, quando teria mudado a denominação para Praça da Independência (Alves, Figueiredo \& Paiva, 2010, p. 14). Seria uma herança deste período o coreto, existente ainda hoje (Figura 9). No local, eram realizadas apresentações culturais e cívicas, manifestações da religiosidade popular e atos políticos.

Com seus canteiros geométricos, coreto, chafariz, árvores, lagos e flores, essa praça tornou-se, então, exemplo para apreciação estética (Figuras 8 e 9). Alves, Figueiredo e Paiva (2010) destacam que estudiosos da arquitetura colonial mineira, como Sylvio Vasconcelos, consideraram-na uma das mais notáveis de Minas Gerais, com destaque ao tamanho, à sensação de conforto e ao ajardinamento típico do século XIX.

A bem da verdade, a Praça Gomes Freire sedimentou-se como importante espaço de convívio social, com "grande vocação para a reunião e celebração social" (Alves, Paiva \& Garcia, 2016, tradução nossa, p. 350). É ali que frequentemente se reúnem os moradores para conversar, descansar, apreciar a paisagem, assim como para participar de eventos sociais mais corriqueiros. A apropriação pela comunidade fica evidenciada pela própria nomenclatura popular atribuída à praça, conhecida como Jardim de Mariana, ou simplesmente Jardim. 
Figura 8: Praça Gomes Freire.

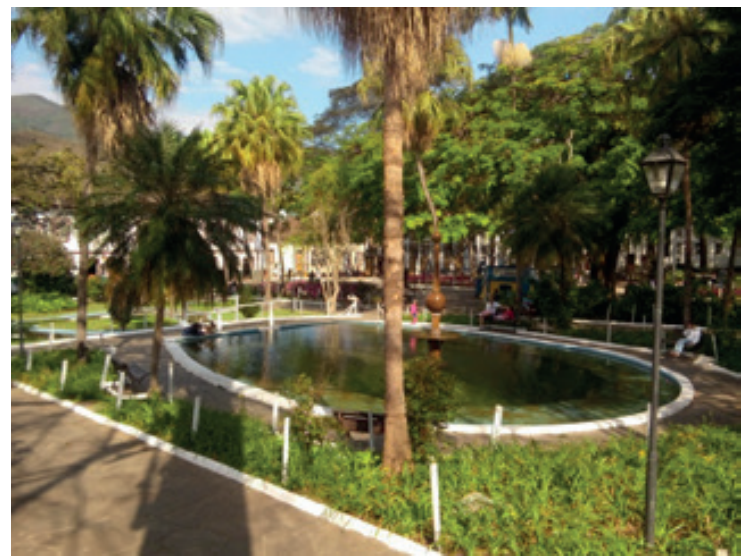

Fonte: Pesquisa de campo (2017).

Figura 9:Praça Gomes Freire.

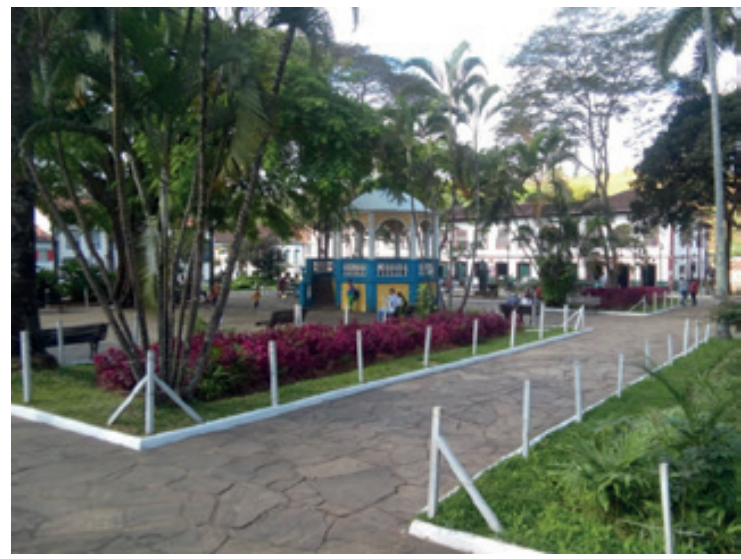

Fonte: Pesquisa de campo (2017).

A sinestesia urbana proporcionada pela praça pode ser percebida em um livreto organizado por uma professora da escola pública que também recebeu o nome de Gomes Freire. Os textos foram escritos por alunos: "A Praça Dr. Gomes Freire, (sic) é muito bonita. Lá tem um lago, você já viu? Lá tem peixinhos e árvores. Há pé de coqueiros, há coreto. Lá também tem pipoqueiro" (Ana Cecília in Malta, 1999). De fato, a paisagem natural, emoldurada pelas construções coloniais no entorno, faz também com que esse seja um cenário bastante apropriado para registros fotográficos e audiovisuais por turistas.

\section{Experiências do turista, significações e funções de praças: escolhas e procedimentos metodológicos}

No que se refere à qualidade do espaço público e seu emprego para a experiência turística, é forçoso percebê-lo do ponto de vista do visitante. As representações produzidas pelo turista baseiam-se em percepções do espaço que são, comumente, compartilhadas em rede na atualidade (Richards, 2015). Desta forma, tornam-se peças-chave para a imagem de destinos turísticos (Miossec, 1977, Pearce, 2014), bem como para a governança e sustentabilidade turística (Vera Rebollo \& Ivars Baidal, 2004; Farinós Dasí, 2008; Pulido-Fernández \& Pulido-Fernández, 2014; Segittur, 2015). 
Essa orientação vem ao encontro da gestão turística que almeja "novas formas de tomada de decisão coletivas, em questões que [...] buscam promover processos de inovação social, o fortalecimento dos atores mais frágeis do sistema e a mudança das dinâmicas turísticas que reproduzem impactos negativos" (Velasco Gonzáles, 2014, p. 19, tradução dos autores). Nesse sentido, numa perspectiva de políticas turísticas, as representações compartilhadas em rede por viajantes tanto se colocam como repositório de informações aplicáveis ao incremento do conhecimento turístico quanto como instrumentos de comunicação, permitindo interação direta com turistas (Velasco González, 2011). Podem ser tomadas, portanto, como um mecanismo útil à inteligência territorial, cujo conceito integra diversos eixos interrelacionados, conforme apresentam, na Figura 10, Luque Gil, Zayas Fernández e Caro Herrero (2015).

Figura 10: Elementos que integram a inteligência territorial

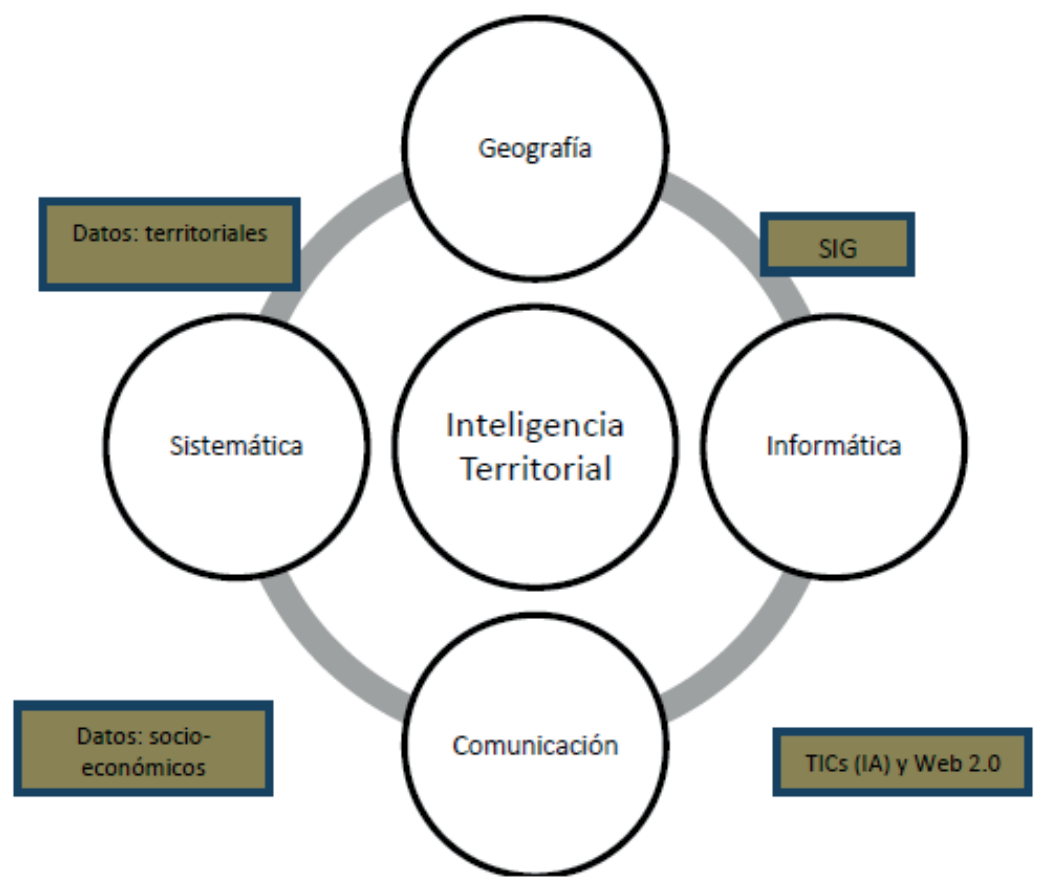

Fonte: Luque Gil, Zayas Fernández e Caro Herrero (2015, p. 6).

O compartilhamento de representações situa-se, mais estritamente, na esfera da comunicação. Contudo, numa dinâmica integrada, possibilita vínculos com a geografia (ao reproduzir aspectos do espaço físico e cultural), a informática (ao alimentar bases de dados) e a sistemática (ao envolver diversos atores, dados e escalas). É, justamente, a gestão racional e participativa deste fluxo contínuo de informações e relações que fundamenta o conceito de inteligência territorial.

O estudo da tipologia ou dos arquétipos das praças, por sua vez, encontra trabalhos desenvolvidos por diversos autores (Matas Colom, Vergara Necochea \& Balbontín Vicuña, 1983; De Angelis, 2000; De Angelis, De Angelis Neto, Barros \& Barros, 2005; Serpa, 2011; Silva, 2015, 2016a, 2016b; Silva, Gândara \& Santos, 2016a, 2016b). Nos modelos propostos por Matas Colom et al. (1983) e De Angelis et al. (2005), classificam-se as praças conforme as funções que desempenham - estética, simbólica, ecológica, psicológica. Desta forma, de acordo com a significação (tipologia), elege-se aqui quatro categorias: significação simbólica, visual, de circulação e recreativa. Evidentemente, é plausível que uma praça apresente várias funções para seus usuários, a depender do que motiva a visita. No entanto, como ressalta De Angelis (2000), é comum uma determinada significação revelar-se mais proeminente. 
Este artigo também tem por base os conceitos propostos por Pine II e Gilmore (1999) sobre a economia da experiência, que se apresenta como uma leitura aplicável ao turismo. Por isso, tornou-se uma teoria aplicada como estratégia para planejar destinos turísticos competitivos (Gândara, Mendes, Moital, Ribeiro \& Goulart, 2012; Horodyski, Manosso \& Gândara, 2014). Pine II e Gilmore (1999) propõem quatro dimensões da experiência de consumo, as quais se pode relacionar à experiência de visitação: entretenimento, aprendizagem, contemplação e evasão.

\section{Quadro 1: Classificação de praças a partir de suas significações}

\begin{tabular}{|c|c|c|}
\hline Tipologias das Praças & Funções das Praças & Dimensões da Experiência \\
\hline Visual & Estética / Simbólica / Ecológica & Contemplação / Aprendizagem / Evasão \\
\hline Simbólica & Simbólica / Psicológica & Evasão / Aprendizagem \\
\hline Recreativa & Ecológica / Psicológica & Entretenimento / Evasão \\
\hline Circulação & Estética / Simbólica & Entretenimento / Contemplação \\
\hline
\end{tabular}

Fonte: Autores com base em Silva (2015, 2016a, 2016b), Silva et al. (2016a, 2016b), Matas Colom et al. (1983), Pine II e Gilmore (1999) e De Angelis et al. (2005).

Como premissa metodológica, esta pesquisa configura-se como exploratória, descritiva e de cunho qualitativo. Estabelece, então, uma classificação fundamentada na percepção e representação de visitantes, consubstanciadas na tipologia das significações e funções de praças e das experiências turísticas (Quadro 1). Para isso, além de um levantamento histórico-geográfico, adota como suporte empírico imagens fotográficas e avaliações de turistas sobre as praças da Sé, Gomes Freire e Minas Gerais, disponibilizadas no website TripAdvisor.

Procedimentos netnográficos ajustam-se, portanto, a esta investigação, uma vez que permitem interpretação humana - ou manual, como tratam Kozinets $(1998,2002)$ e Turpo (2008) - de dados recolhidos e filtrados na web. Trata-se de uma técnica socioantropológica relativamente recente na pesquisa acadêmica, cujo foco direciona-se à análise do comportamento no ambiente virtual (Rocha \& Montardo, 2005; Amaral, Natal \& Viana, 2008). Como ferramenta metodológica, seu emprego é recomendado em contextos diversos, tanto para o estudo das ciberculturas quanto para compreensão de comunicações e fenômenos atinentes ao ciberespaço. Conforme postula Kozinets (1998), conforma-se como um trabalho de campo, mediado por computador, que resulta em uma descrição textual.

$\mathrm{Na}$ análise das avaliações, foram agrupadas, então, imagens fotográficas e depoimentos dos visitantes sobre as praças em foco. Houve a identificação de 41 avaliações (com 20 fotografias) da Praça da Sé, 167 avaliações (com 101 fotografias) da Praça Gomes Freire e 432 avaliações (com 376 fotografias) da Praça Minas Gerais. Aquelas que apresentaram comentários e registros fotográficos, concomitantemente, foram selecionadas e agrupadas de acordo com a significação (tipologia) das praças proposta por Matas Colom et al. (1983) e De Angelis et al. (2005), além de relacionadas com as dimensões da experiência propostas por Pine II e Gilmore (1999).

Para efeito de síntese na divulgação de resultados, considerou-se oportuna a seleção de avaliações de turistas que fossem representativas das classificações encontradas sobre cada praça, cotejando-as com o substrato histórico-geográfico sobre o urbanismo setecentista de Mariana e informações levantadas durante a pesquisa de campo, realizada entre os dias 16 e 26 de julho de 2017. Nesta investigação, buscou-se captar a dinâmica socioespacial in loco, a fim de confirmar ou refutar subsídios bibliográficos, além de agregar dados primários ao estudo.

\section{Análise e discussão de resultados}

Para cada uma das praças, foram identificadas fotografias e depoimentos publicados por visitantes no site TripAdvisor. Nos resultados, estão relacionadas significações com as funções desempenhadas pelas praças (Matas Colom et al., 1983; De Angelis, 2000; De Angelis et al., 2005), bem como analisadas experiências manifestadas pelos visitantes com base nas dimensões da experiência (Pine II \& Gilmore, 1999). 


\subsection{Praça da Sé}

Duas tipologias destacam-se em relação à Praça da Sé, com predominância da categoria "Circulação". Nesse sentido, a visitante identificada por "Laura Regina", de Aracaju/SE, registrou a paisagem apresentada na Figura 11. A visitante intitula a sua avaliação "Nossa história" e complementa com o seguinte depoimento: "Linda praça com diversos restaurantes em volta, além de ser próximo de várias casas históricas, do Museu Arquidiocesano de Arte Sacra, da Casa de Câmara e Cadeia, e da Praça Minas Gerais, e da Rua Direita etc". Nota-se que tanto a imagem quanto a menção à beleza remetem mais às construções do entorno ou próximas do que ao espaço da praça em si.

\section{Figura 11: Praça da Sé}

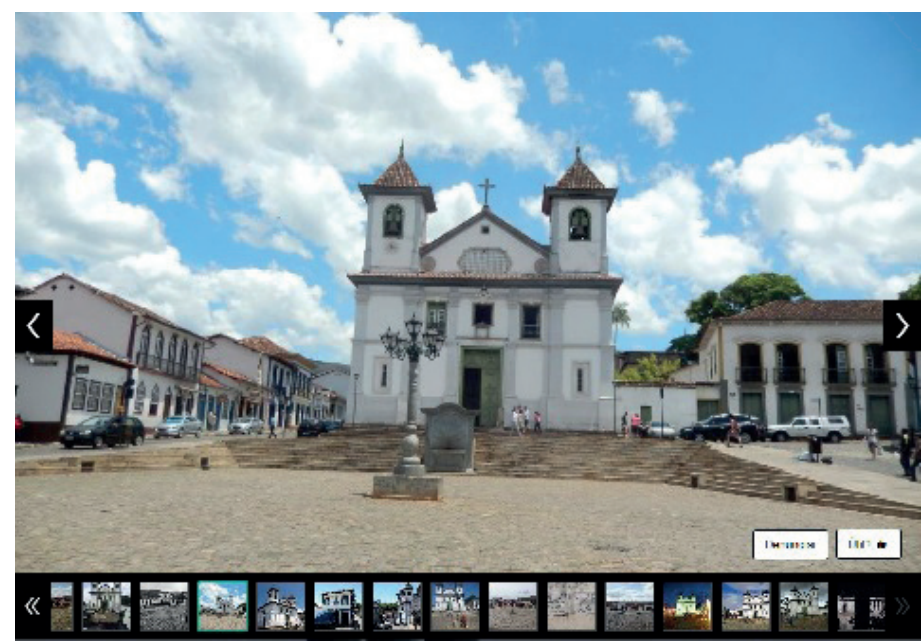

Por: "Laura Regina" (Fev. 2017)

Fonte: TripAdvisor, 2017.

Figura 12: Praça da Sé

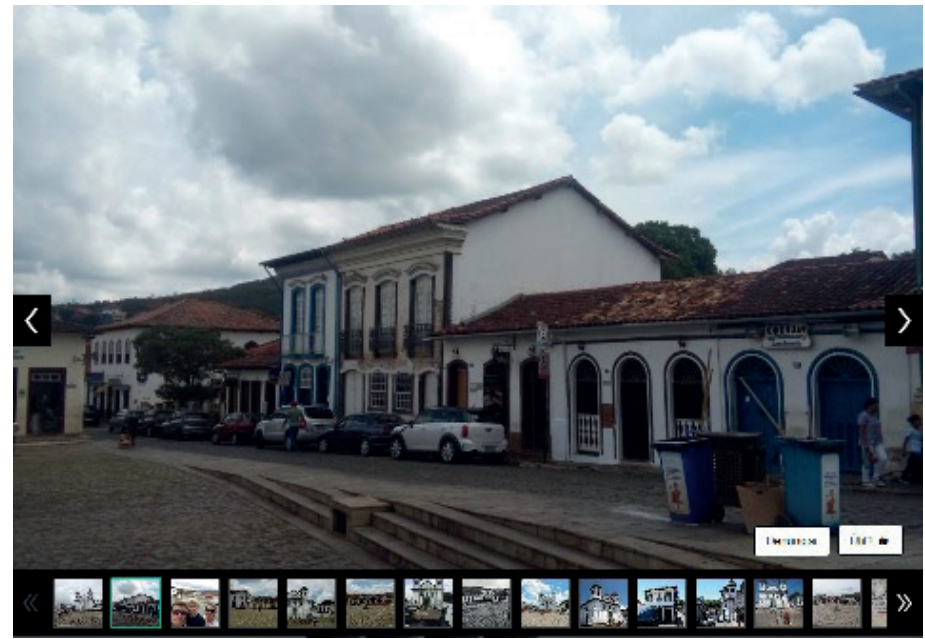

Por: "Gustavo Teixeira" (Nov. 2015)

Fonte: TripAdvisor, 2017. 
Na Figura 12, registrada pelo visitante "Gustavo Teixeira", de Belo Horizonte/MG, já se percebem mais elementos que correspondem à praça, o que é reforçado no comentário do visitante. Nessa avaliação, além da categoria "Circulação", observa-se também a tipologia "Simbólica". O turista destaca a Catedral da Sé e o comércio: "Linda praça, próximo da Rua da Direita. A Catedral Basílica da Sé fica em frente. Ao redor tem um bom comércio".

Nessas avaliações, podemos perceber as dimensões da experiência de entretenimento (principalmente pela presença de restaurantes no entorno, ou por sua associação a outros atrativos localizados próximos desta praça), e de aprendizagem, notadamente do patrimônio religioso. Nesse aspecto, corroborando com Gomes (1997), a fusão desses domínios da experiência se dá por esse espaço ser um símbolo, que permite perpassar emoção na sua imagem e na biografia do sujeito.

As representações predominantes aqui encontram respaldo no levantamento histórico-geográfico acerca dessa praça, cuja região perdeu importância ao longo da evolução urbanística de Mariana, mas ainda conserva relevância do ponto de vista patrimonial (Vasconcelos, 1999). Nesse sentido, a presença da Catedral da Sé revela-se como essencial ao simbolismo e à atratividade turística deste espaço. Por outro lado, o cruzamento de vias importantes, bem como o comércio no entorno, favorece o trânsito frequente de pedestres e carros pelo local (Bastos, 2015).

Com efeito, o destaque a esses atributos guarda relação direta também com as intervenções realizadas na Praça da Sé após o tombamento de Mariana como Monumento Nacional (Fonseca, 1995). Na ausência de outros elementos de destaque, a apropriação pelos próprios moradores relaciona-se à circulação e ao seu valor simbólico, em virtude do significado religioso e histórico do local, do que propriamente em função do aspecto físico, tampouco estético ou socializante.

\subsection{Praça Gomes Freire}

Duas tipologias também se destacam em relação à Praça Gomes Freire. Na categoria "Recreativa", o visitante "Afonsoccr", de Santos Dumont/MG, registra a fotografia apresentada pela Figura 13. Na imagem, percebe-se uma apresentação de músicos, próximo ao coreto da praça. Na descrição da avaliação, o visitante intitula "Bela e nostálgica" e complementa com o depoimento: "A visita a Mariana nos proporcionou momentos de prazer histórico e cultural, mas essa simpática praça localizada no Centro nos surpreendeu pela estrutura arborizada, limpeza, calmaria e outros valores que desapareceram de suas similares em muitas cidades do Brasil. Por ser um domingo, ainda fomos premiadíssimos com uma audição de uma banda de música local que atraiu as pessoas que circulavam pelas ruas ou saiam das missas, o que foi emocionante".

O relato dessa experiência associada à imagem fotográfica aponta a dimensão evasão, que diz respeito à capacidade de fazer com que o visitante fique imerso nas atividades que lhe são propostas (Pine II e Guilmore, 1999).

Figura 13: Praça Gomes Freire, por: “Afonsoccr” (Set. 2016)

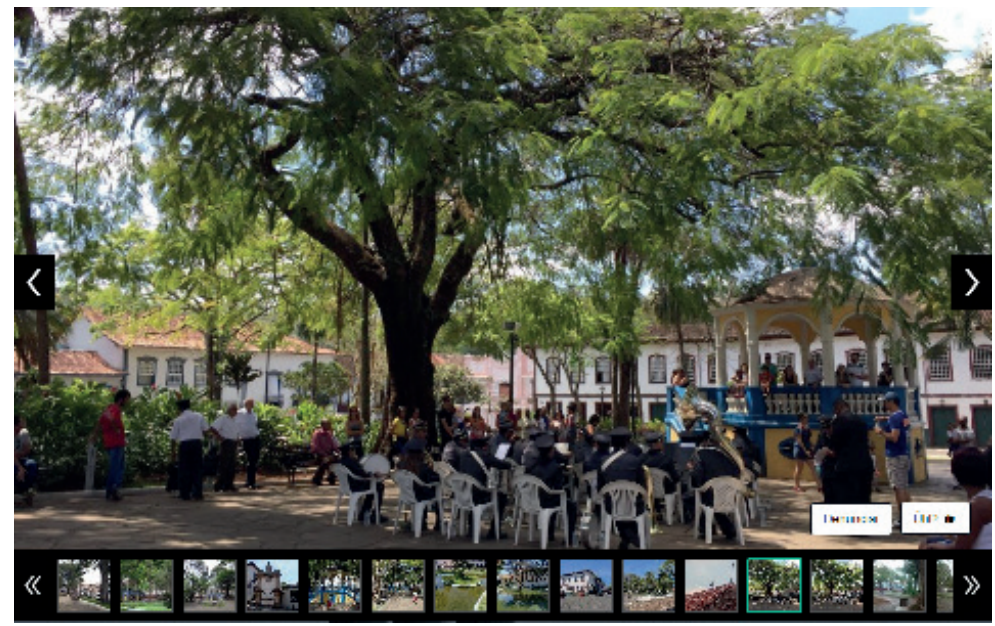

Fonte: TripAdvisor, 2017. 
Como significação "Visual”, o visitante "Grimble Grumble Family", de Niterói/RJ, registrou uma fotografia panorâmica para representar a sua experiência com maior amplitude de detalhes (Figura 14). Ele intitulou a avaliação como "Praça bucólica", comentando na descrição: "Pracinha bonita, com jeito de cidade do interior mesmo. Possui um laguinho, coreto bancos e muito verde. Ao seu redor, vários restaurantes e lojinhas".

Figura 14: Praça Gomes Freire, por: “Grimble Grumble Family” (Set. 2016).

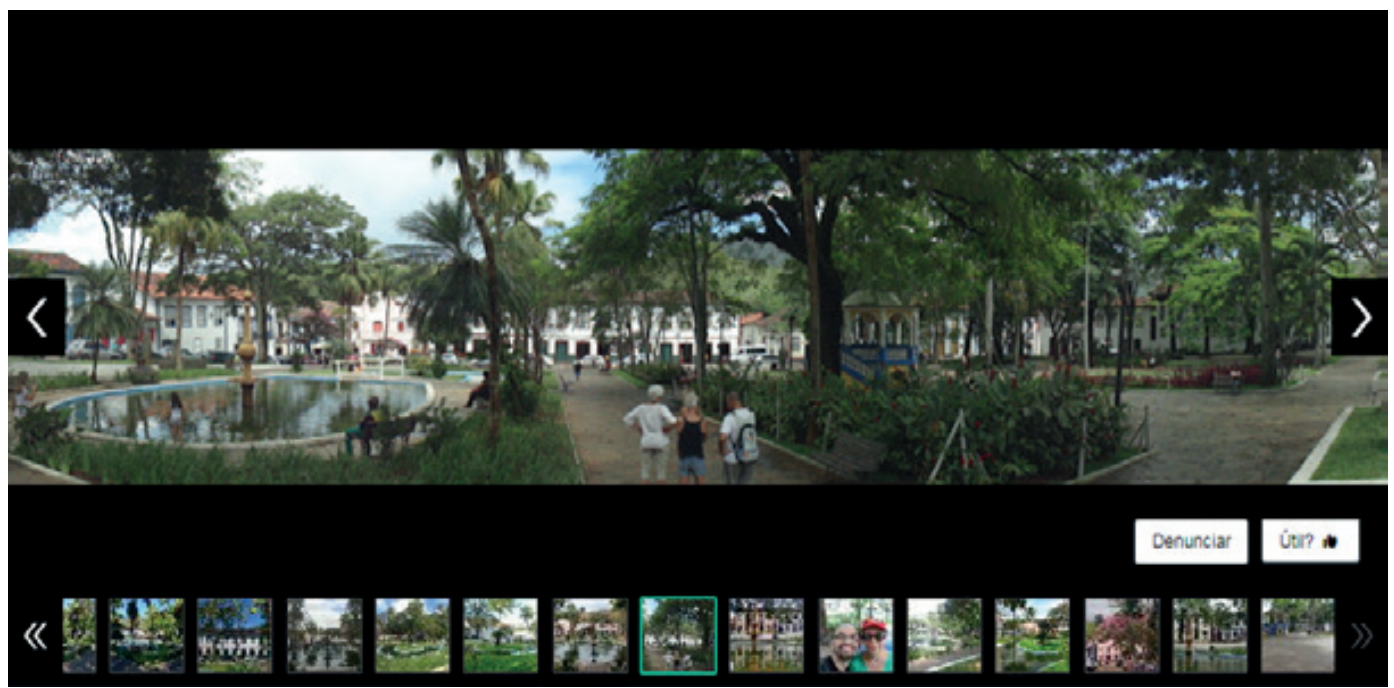

Fonte: TripAdvisor, 2017.

Ainda no âmbito da categoria "Visual", identificou-se a dimensão da experiência de contemplação por meio da fotografia apresentada pela Figura 14. Tal caracterização foi possibilitada pelo destaque a elementos que levem o visitante à tomada de decisão de permanecer no local ou de eleger o ângulo fotográfico que melhor capte a paisagem, com o objetivo de registrar a experiência. A praça atua, portanto, como elemento convidativo, valendo-se de seu valor estético (Ferrara, 1988; Pine II e Guilmore, 1999; Barretto, 2002).

Com efeito, os resultados aqui obtidos corroboram com a vocação e características da Praça Gomes Freira destacadas por Figueiredo e Paiva (2010) e Alves, Paiva e Garcia (2016). Além dos reconhecidos atributos estéticos, o acesso é facilitado pela disposição centralizada e plana. Sua dimensão, cobertura vegetal e variedade do mobiliário urbano oferecem conforto ambiental, possibilitando a permanência por longos períodos. Características que atraem variado perfil de usuários. Durante o dia, notam-se jovens, idosos, famílias com crianças, pessoas de comunidades rurais e cidades vizinhas que recorrem ao comércio e serviços de Mariana, vendedores ambulantes de artesanato, entre outros tipos. À noite, é comum a presença de estudantes, que se apropriam da praça como uma espécie de extensão do espaço da universidade. Ou seja, há um efetivo compartilhamento entre o uso para fins turísticos e a apropriação pela população local.

\subsection{Praça Minas Gerais}

Assim como agregou a ampla maioria das avaliações da amostra, $75 \%$ do total, a Praça Minas Gerais apresentou o maior número de tipologias distintas dentre as três praças estudadas. Na categoria "Simbólica", o visitante "MarceloR" enfatiza as igrejas, incluindo menção a um aspecto negativo e descreve: "Conjunto arquitetônico maravilhoso. Sem dúvida, a maior atração de Mariana. A praça possui duas igrejas. Uma de frente para a outra. Infelizmente, estavam fechadas. Em frente, está a Casa Câmara Legislativa da Cidade" (Figura 15). Nessa avaliação, é possível identificar as dimensões de experiência contemplação e evasão. 
A dimensão contemplação é comprovada também se observada a Figura 16, que apresenta fotografia registrada pelo visitante "MarceloB", de Sorocaba/SP. Na avaliação, o visitante faz referência à significação "Circulação", quando intitula: "Parada obrigatória". Mas, na sequência da avaliação, entrelaçam-se significação "Simbólica" e "Visual" na descrição do visitante: "Uma praça sem igual, com a 'igrejas gêmeas', pelourinho e antiga cadeia, forma um cartão-postal e uma viagem ao passado...".

Figura 15: Praça Minas Gerais, por: "MarceloB” (Jun. 2017).

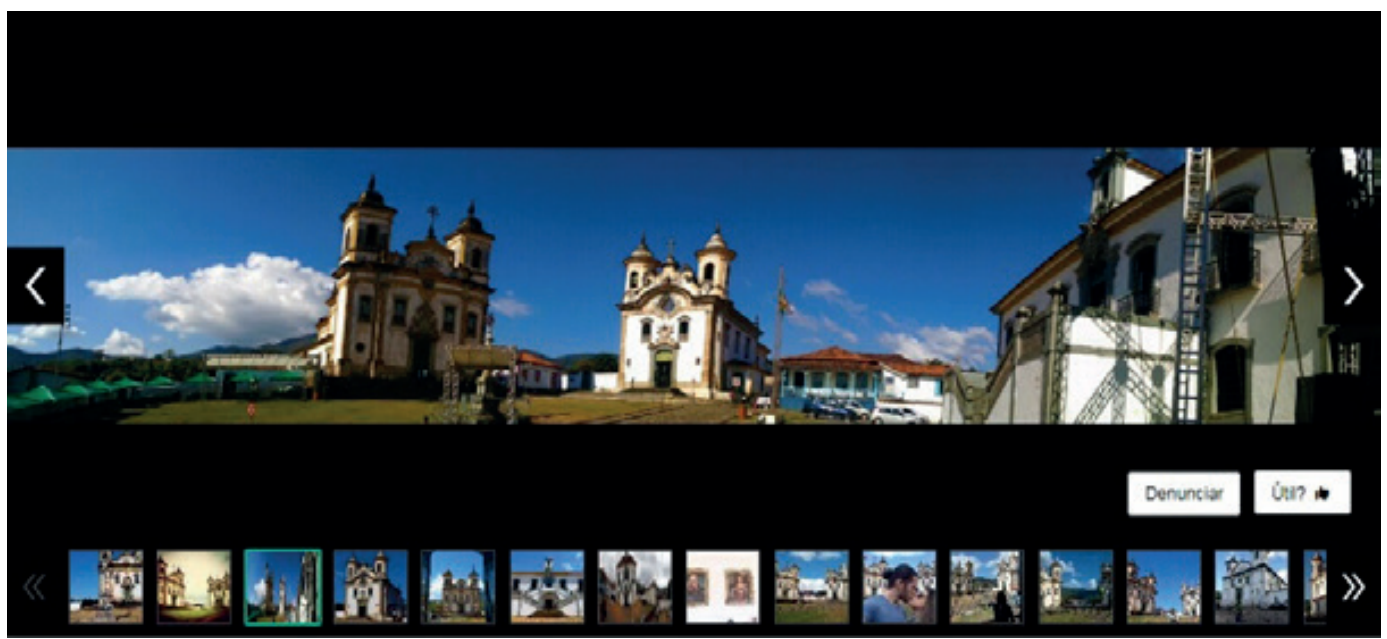

Fonte: TripAdvisor, 2017.

Figura 16: Praça Minas Gerais, por: "MarceloR” (Ago. 2017).

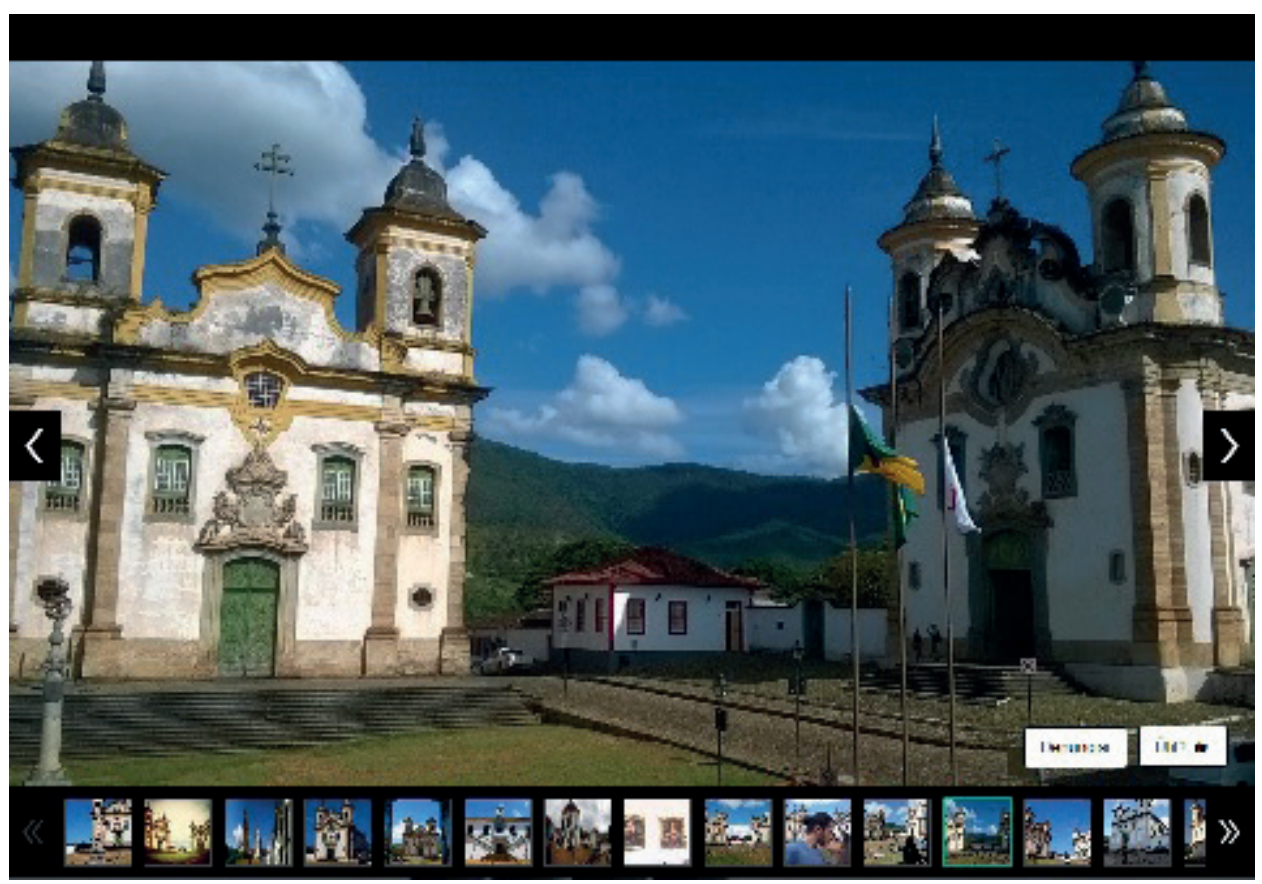

Fonte: TripAdvisor, 2017. 
As percepções e representações predominantes encontradas aqui também se autenticam ao emparelhá-las com o levantamento histórico-geográfico (Antunes \& Silveira, 2015; Ferreira \& Ferreira, 2009, Marton \& Pereira, 2007). Notoriamente, saltam aos olhos, nas avaliações analisadas, os elementos que fazem desta uma praça emblemática para Mariana: as igrejas São Francisco e Nossa Senhora do Carmo, o pelourinho e a Casa de Câmara e Cadeia, separadamente ou em conjunto. E sobretudo quando representadas conjuntamente, reforçam o simbolismo desse espaço para a memória e a iconografia de Minas Gerais.

\section{Considerações finais}

As praças evocam a noção de centralidade urbana e podem ser traduzidas como local de encontro, onde se desenvolveram fatos importantes e que tanto inspiram o presente quanto impulsionam renovadas apropriações. Portanto, enquanto espaço público essencial, além de atuar como agente físico que harmoniza o ambiente circundante, é também um elemento que referencia a paisagem e possibilita a seus usuários a realização de diversas atividades e experiências. Desse modo, com o passar do tempo, a praça adquire uma conotação simbólica que seu observador/usuário retém na memória enquanto ponto de referência do presente e do passado, como se percebeu neste estudo sobre as praças de Mariana.

Como se dá, então, o diálogo entre temporalidades antigas e atuais, primitivas e contemporâneas, destes espaços referenciais, a partir da percepção de visitantes? Com efeito, o elo responsável por essa interface passa pelas significações das praças, com base nos seus tipos, funções e experiências proporcionadas, que se mostraram chaves importantes para contemplar esse problema. Nesse sentido, sentidos de cunho simbólico, visual, recreativo e de circulação ficaram evidenciados entre as tipologias identificadas a partir da imagens e depoimentos obtidos no TripAdvisor. E em cada uma das praças, uma das classificações apresentou-se mais acentuada: Praça da Sé - Circulação, Praça Gomes Freire - Visual, Praça Minas Gerais - Simbólica. Nesse sentido, a reputação online emerge como um canal importante tanto para a governança turística quanto para a gestão do espaço público, de modo geral. A possibilidade de comunicação constante com o turista e com o próprio morador surge como oportunidade de planejar e desenvolver políticas turísticas de forma compartilhada, numa perspectiva de inteligência territorial.

Complementarmente, a compreensão das dimensões da experiência contribui para uma reflexão sobre as possibilidades de se planejar espaços que satisfaçam moradores e surpreendam visitantes. A contemplação e evasão proporcionadas pela Praça Minas Gerais e Gomes Freire ou a aprendizagem e o entretenimento na Praça da Sé são indicativos importantes para dinamização turística de Mariana. É possível agregar novas experiências a esses espaços? O aprofundamento de estudos nessa linha pode favorecer a envergadura competitiva, a partir da identificação de elementos espaciais físicos e humanos com características adequadas para serem potencializados como atrativos experienciais.

Notadamente, a pesquisa buscou unir informações disponíveis no TripAdvisor - uma ferramenta de comunicação destinada a prováveis visitantes - com levantamento histórico-geográfico e informações manifestadas pela dinâmica socioespacial in loco. Do ponto de vista de cidade como espaço sociocultural, acredita-se na importância da valorização e preservação das praças de Mariana, assim como demais espaços públicos. Uma vez que isso seja percebido pelo visitante, incrementam-se experiências capazes de agregar sustentabilidade ao turismo e valor à imagem do destino.

Cabe ressaltar que Mariana sofre graves consequências da maior tragédia ambiental do Brasil. A economia do município mais afetado pelo rompimento da barragem de Fundão ${ }^{7}$, em novembro de 2015, é dependente da mineração (Rodrigues, 2016, 2017). Com a inatividade da empresa Samarco, a arrecadação caiu de 27 milhões para 17,5 milhões de reais e o desemprego atinge 23,5\% da população (Estadão, 2017). Nesse cenário, as pessoas estão mais sensíveis ao turismo, que figura não apenas como uma alternativa à estagnação econômica, como também fonte de recuperação da autoestima dos moradores.

\section{Bibliografia}

Alves, S. F.; Figueiredo, M. A. \& Paiva, P. D.

2010. História da Praça Gomes Freire: O Jardim de Mariana. Lavras: UFLA.

Alves, S. F., Paiva; P. D. \& Garcia, C. S.

2016. Largo do Rossio to a garden: the genesis of the Gomes Freire's square in Mariana MG. Ornamental Horticulture - Revista Brasileira de Horticultura Ornamental, 22(3): pp. 350-360. 
Amaral, A., Natal, G., \& Viana, L.

2008. Netnografia como aporte metodológico da pesquisa em comunicação digital. Sessões do Imaginário, 13: 34-40.

Antunes, Á. d. \& Silveira, M. A.

2015. Casa de Câmara e Cadeia: espaços e símbolos do poder em Mariana (século XVIII). In: C. A. Pereira et al. (Orgs.), O espaço e os construtores de Mariana (século XVIII) (pp. 15-36). Outro Preto: Ed. UFOP. Barretto, M.

2002. Espaço Público: usos e abusos. In: Yázigi, E., Carlos, A. F. A., Cruz, R. C. A. Turismo: espaço, paisagem e cultura. 3 ed. São Paulo: Hucitec.

Bastos, R. A.

2015. A fábrica artístico-construtiva em Minas Gerais no século XVIII: preceitos, agentes e procedimentos dedicados ao decoro das povoações. In: C. A. Pereira et al. (Orgs.), O espaço e os construtores de Mariana (século XVIII) (pp. 61-94). Ouro Preto: Ed. UFOP.

Câmara Municipal de Mariana

2017. Histórico. Acesso em 18 de ago de 2017, disponível em Câmara de Mariana: http://www.camarademariana.mg.gov.br/mariana

Carvalho, R. A. \& Vieira, L. C.

2007. Grupo escolar de Mariana: política, educação e cotidiano escolar. Anais do XXIV Simpósio Nacional de História - História e multidisciplinaridade: territórios e deslocamentos. 24, pp. 1-8. São Leopoldo: Unisinos.

Climate-data.org.

2017. Clima: Mariana. (Oedheim: AM Online Projects) Acesso em 15 de ago de 2017, disponível em Climate-data.org: https://pt.climate-data.org/location/25091/

De Angelis, B. L.

2000. A praça no contexto das cidades: o caso de Maringá-PR. Tese (Doutorado em Geografia). FFLCH. São Paulo: USP.

De Angelis, B. L.; De Angelis Neto, G.; Barros, G. D. A. \& Barros, R. D. A.

2005. Praças: história, usos e funções. Fundamentum. (Vol. 15). Maringá: EDUEM.

Estadão

2017, 5 nov.. Tragédia de Mariana ainda afeta economia da cidade. Época Negócios. Disponível em: http://epocanegocios.globo.com/Empresa/noticia/2017/11/epoca-negocios-tragedia-de-mariana-ainda-afeta-economia-da-cidade.html. Acesso em: 1 dez. 2017.

Farinós Dasí, J.

2008. Gobernanza territorial para el desarrollo sostenible: estado de la cuestión y agenda. Boletín de la Asociación de Geógrafos Españoles, 46: 11-32.

Ferrara, L. A.

1988. Ver a cidade: cidade, imagem, leitura. São Paulo: Nobel.

Ferreira, L. D. \& Ferreira, L. R.

2009. Festas religiosas: uma manifestação cultural de Mariana. Ouro Preto: ETFOP.

Fonseca, C. D.

1995. Mariana: gênese e transformação de uma paisagem cultural. Universidade Federal de Minas Gerais, Instituto de Geociências. Belo Horizonte: UFMG.

Jan./June 2012. Urbs e civitas: A Formação dos espaços e territórios urbanos nas Minas setecentistas. Anais do Museu Paulista: História e Cultura Material, 20(1): 77-108.

Gândara, J. M. G.; Mendes, J.; Moital, M.; Ribeiro, F. N. S. \& Goulart, L. A.

2012. Planificación estratégica de un circuito turístico hitórico-cultural experiencial: Itabuna-Bahia, Brasil. Estudios y Perspectivas en Turismo, 21: 225-248. Buenos Aires.

Gomes, E. C.

1997. Percepção do ambiente construído: a praça. Tese (Doutorado em Arquitetura). Faculdade de Arquitetura e Urbanismo. São Paulo: USP

Gonçalves, M. T., Sousa \& Ferro, M. J.

2012. A representação da sociedade e do poder real através dos inventários dos bens móveis e dos lançamentos de despesas da Câmara de Mariana, século XVIII. In: C. M. Chaves, M. d. Pires, \& M. S. Maria, Casa de Vereança de Mariana: 300 anos de História da Câmara Municipal (pp. 89-105). Ouro Preto: Edufop/PPGHIS. 
Horodyski, G. S.; Manosso, F. C. \& Gândara, J. M. G.

2014. A pesquisa narrativa na investigação das experiências turísticas relacionadas ao consumo de souvenirs: uma abordagem fenomenológica. Turismo em Análise, 25 (1). São Paulo:USP.

Ibge, Diretoria de Pesquisas, Coordenação de População e Indicadores Sociais

2017. Estimativas da população residente com data de referência $1^{\circ}$ de julho de 2017. Acesso em 15 ago. 2017. Disponível em IBGE Cidades: http://cod2.ibge.gov.br/2VHOK.

Kozinets, R. V.

1998. On Netnography: Initial Reflections on Consumer Research Investigations of Cyberculture. NA - Advances in Consumer Research, 25: 366-371.

2002. The field behind the screen: using netnography for marketing research in online communities. Journal of Marketing Research, 39: 61-72.

Luccock, J.

1942. Notas sobre o Rio de Janeiro e partes meridionais do Brasil (1820). São Paulo: Livraria Martins. Luque Gil, A. M.; Zayas Fernández, B. \& Caro Herrero, J. L.

2015. Los Destinos Turísticos Inteligentes en el marco de la Inteligencia Territorial: conflictos y oportunidades. Investigaciones Turísticas, 10, pp. 1-25. doi:10.14198/INTURI2015.10.01

Malta, V.

1999. Se essa rua fosse minha. Mariana: [s.n.].

Marton, M., \& Pereira, D.

2007. Catálogo de Mariana. Mariana: Secretaria Municipal de Cultura e Turismo.

Matas Colom, J.; Vergara Necochea, A. \& Balbontín Vicuña, P.

1983. Las plazas de Santiago. Santiago: Ediciones Universidad Católica de Chile.

Minas Gerais, Constituição

1989. Constituição do Estado de Minas Gerais. Belo Horizonte: Assembléia Legislativa.

Miossec, J.-M.

1977. L'image touristique comme introduction à la géographie du tourisme. Annales de Géographie, 86(473): 55-70.

Pearce, D. G.

2014. Toward an integrative conceptual framework of destinations. Journal of Travel Research, 53(2): 141-153.

Pine II, J. B. \& Gilmore, J. H.

1999. The Experience Economy: work is theatre \& every business a stage. Massachusetts: Ed. Harvard Business School Press.

Pulido, M. C. \& Pulido, J. I.

2014. ¿Existe gobernanza en la actual gestión de los destinos turísticos? Estudio de casos. Pasos: Revista de Turismo y Patrimonio Cultural, 12(4): 685-705.

Prefeitura de Mariana

2017. Histórico. Acesso em 18 de ago de 2017, disponível em Prefeitura de Mariana: http://www.mariana. mg.gov.br/historico

Richards, G.

2015. The new geographies of tourism: Space, place and locality. In: D. Dredge and S. Gyimóthy (eds.) Tourism and collaborative consumption: perspectives, politics, policies and prospects, Dordrecht: Springer.

Rocha, P. J., \& Montardo, S. P.

2005. Netnografia: incursões metodológicas na cibercultura. E-Compós, 4: 1-22.

Rodrigues, L.

2016, 4 nov. Mariana vive desafio de diversificar receitas, mas retorno da Samarco é plano A. Agência Brasil. Disponível em: http://agenciabrasil.ebc.com.br/geral/noticia/2016-11/mariana-vive-desafio-de-diversificar-receitas-mas-retorno-da-samarco-e-plano. Acesso em: 5 nov. 2017.

2017, 1 set.. Municípios querem ser ressarcidos por queda de receita após tragédia de Mariana. Disponível em: http://agenciabrasil.ebc.com.br/geral/noticia/2017-09/municipios-querem-ser-ressarcidos-por-queda-de-receita-apos-tragedia-de. Acesso em: 1 dez. 2017.

Saint-Hilaire, A.

1975. Viagem pelas províncias do Rio de Janeiro e Minas Gerais. Belo Horizonte, São Paulo: Itatiaia, USP. Segittur.

2015.Informe destinos turisticos inteligentes: construyendo el futuro. Madri: Segittur. 
Serpa, A.

2011. O espaço público na cidade contemporânea. São Paulo: Contexto.

Silva, S. R. X.

2015. A praça como espaço de experiências turísticas. In: XII Seminário ANPTUR, 2015, Natal. Anais do Seminário da ANPTUR. São Paulo: ANPTUR, p. 1-13.

Silva, S. R. X.

2016a. A praça do Japão (Curitiba-PR): lugar, sentimento e vida social (pp. 143-171). In: Santos, S. R.; Santos, P. C. (Orgs.). Gestão urbana e desenvolvimento local e regional: estudos de caso no Brasil. São Luís: EDUFMA, 2016.

S. R. X. (2016b). Qualidade do espaço público e experiências de turistas em praças de Curitiba-PR e Ilhéus-BA. In: Anais do Encontro Nacional de Geógrafos. São Luís: AGB/UFMA.

Silva, S. R. X.; Gândara, J. M. G.; Santos, S. R.

2016a. Turismo de experiência em centros históricos: uma análise sobre praças de Curitiba-PR e Ilhéus-BA. In: VIII SIMPGEO - Simpósio Paranaense de Pós-Graduação e Pesquisa em Geografia: Anais. Marechal Cândido Rondon: Unioeste, p. 301-308.

Silva, S. R. X.; Gândara, J. M. G.; Santos, S. R.

2016b. "Educação Patrimonial e Experiência Turística em praças localizadas em centros históricos pp. 204-217)". In: Anais do SIMPOLITUR: I Simpósio Regional de Políticas de Turismo e Arranjos Produtivos Locais. Aracaju: IFS.

Tedeschi, D. M.

2015. "Os cahafarizes de Mariana: o abastecimento de água no século XVIII (pp. 121-136)" In: C. A. Pereira et al. (Orgs.), O espaço e os construtores de Mariana (século XVIII). Ouro Preto: Ed. UFOP. Turpo, O. W.

2008. La netnografía: método de investigación en Internet. Educar, 42: 81-93.

Vasconcelos, D. d.

1999. História Antiga de Minas Gerais (4. ed.). Belo Horizonte: Itatiaia.

Velasco Gonzáles, M.

2011. La política turística: una arena de acción autónoma. Cuadernos de Turismo, 27: 953-969.

2014. Gobernanza turística: ¿Políticas públicas innovadoras o retórica banal? Caderno Virtual de Turismo. Edição especial: Hospitalidade e políticas públicas em turismo, 14(1): 9-22.

Vera Rebollo, J. F. \& Ivars Baidal, J. A.

2004. Indicadores de sostenibilidad para destinos maduros: balances y propuestas de aplicación. In: Conferencia de la Organización Mundial de Turismo "Creando Estructuras para la Investigación y la Educación en Política Turística y Gestión de Destinos”, Madrid, 2-3 jun. 2004. Disponível em: http://hdl.handle.net/10045/20481. Acesso em: 8 set. 2016.

\section{Notas}

https://www.TripAdvisor.com.br/

2 Situada na Bacia do Rio Doce, há $110 \mathrm{~km}$ de Belo Horizonte, fica localizada na vertente sul da Serra do Espinhaço, a 697 metros de altitude. Integra a Zona Metalúrgica de Minas Gerais, conhecida como Quadrilátero Ferrífero, com população estimada de 59.857 habitantes, segundo o IBGE (2017).

3 Situada numa região com intensa atividade mineradora, Mariana é foco de ações promocionais de várias empresas deste ramo, que frequentemente divulgam peças publicitárias alusivas ao município, especialmente no aniversário. https://pt.climate-data.org/location/1006081/

5 Esta foi uma das denominações adotadas em Minas Gerais para designar as terras doadas pela Coroa Portuguesa às Câmaras locais para constituição do seu patrimônio.

6 Expressão religiosa do catolicismo, de origem medieval. Celebrada como festividade popular, representa a batalha dos cristãos contra os mouros, a partir da simulação de combates entre cavaleiros enfeitados com opulência e armados com lanças.

7 Localizada no distrito de Bento Rodrigues, a $35 \mathrm{~km}$ da região central de Mariana.

Recibido:

$13 / 12 / 2017$

Reenviado:

$08 / 02 / 2018$

Aceptado:

$12 / 02 / 2018$

Sometido a evaluación por pares anónimos 